\title{
RANCANGAN SISTEM SIKLUS AKUNTANSI PADA BANK SAMPAH
}

\author{
Anis Indah Kurnia dan Dadang Romansyah \\ Program Studi Akuntansi Syariah \\ Sekolah Tinggi Ekonomi Islam SEBI \\ Email: anisindahkurnia@gmail.com
}

\begin{abstract}
This study aims to formulate a system of accounting cycle on trash bank. This study used descriptive methods and qualitative data. This study's subjects consisted of respondents and the data library that collected by interviews, documentation and literature. Analysis was done by analyze the data to understand the process of accounting cycle, preparing the system, the last summed up the results of analysis. The study found a system of financial records and financial statements based on SAK ETAP and some contract in PSAK Sharia. Accounting system has a preparation, recording and classification stage. The preparation stage such as chart of account, price list and customers list. The recording stage such as ledgers: trash inventory, savings cooperatives, list of net income cooperatives, list of savings, list of lending, list of electrical and pulse supplies and special journals: purchase of trash, sales of trash, saving of trash, cash receipts and cash payments. The classification stage such as general ledger, adjusting entries, trial balance. Then the system of financial statements consist of balance sheet, income statement, equity statement, cash flow statement and notes to the financial statements. Finally, for the preparation next period there are after closing journal and trial balance after closing.
\end{abstract}

Keywords: accounting cycle, financial records, financial statements, trash bank

\section{PENDAHULUAN}

Permasalahan sampah masih menjadi pekerjaan rumah yang besar bagi Indonesia. Saat ini, Indonesia merupakan negara dengan penduduk terbanyak keempat di dunia, dengan total penduduk sebanyak 237.000.000. Diperkirakan jumlah penduduk ini akan bertambah menjadi 270.000.000 pada tahun 2025 . Dengan penduduk sebanyak itu, diperkirakan akan dihasilkan sampah sebanyak 130.000 ton/ hari. Ini merupakan potensi yang besar sebagai sumber daya yang dapat di daur ulang, tetapi saat ini sebagian besar masih menjadi sumber penyebab polusi. (Kementerian Lingkungan Hidup, 2014).

Pemerintah mengeluarkan Undang-Undang Nomor 18 tahun 2008 tentang Pengelolaan Sampah beserta Peraturan Pemerintah Nomor 81 tahun 2012 tentang Pengelolaan Sampah Rumah Tangga dan Sampah Sejenis Rumah Tangga sebagai salah satu dari langkah nyata mereka. Peraturan tersebut mengamanatkan perlunya perubahan paradigma yang mendasar dalam pengelolaan sampah yaitu paradigma kumpul angkut buang menjadi pengolahan yang bertumpu pada 
pengurangan sampah dan penanganan sampah. Kegiatan pengurangan sampah bermakna agar seluruh lapisan masyarakat, baik pemerintah, dunia usaha maupun masyarakat luas melakukan kegiatan pembatasan timbulan sampah, pendauran ulang dan pemanfaatan kembali sampah atau yang lebih dikenal dengan sebutan Reduce, Reuse dan Recycle (3R) melalui upaya-upaya cerdas, efisien dan terprogram. (Kementerian Lingkungan Hidup, 2013).

Bank sampah adalah salah satu strategi penerapan 3R dalam pengelolaan sampah di tingkat masyarakat. Melalui bank sampah, akhirnya ditemukan satu solusi inovatif untuk "memaksa" masyarakat memilah sampah. Dengan menyamakan kedudukan sampah dengan uang atau barang berharga yang dapat ditabung, masyarakat akhirnya terdidik untuk menghargai sampah sesuai jenis dan nilainya sehingga mereka mau memilah sampah. (Kementerian Lingkungan Hidup RI, 2014).

Dikatakan oleh Assisten Deputi Urusan Pengelolaan Sampah Kementrian Lingkungan Hidup bahwa hingga Desember 2012 sebanyak 1.195 bank sampah telah dibangun di 55 kota di seluruh Indonesia. (Kementerian Lingkungan Hidup RI, 2014). Data terbaru dari Kementerian Lingkungan Hidup bahwa per Agustus 2014 sebanyak 1.703 di seluruh Indonesia dengan rincian sebagai berikut.

Tabel 1. Rekap Bank Sampah Seluruh Indonesia Tahun 2014

\begin{tabular}{|r|l|r|r|r|r|}
\hline No & \multicolumn{1}{|c|}{ Provinsi } & $\begin{array}{c}\text { Jumlah Bank } \\
\text { Sampah }\end{array}$ & \multicolumn{1}{|c|}{$\begin{array}{c}\text { Jumlah Nasabah } \\
\text { (orang) }\end{array}$} & $\begin{array}{c}\text { Sampah Terolah } \\
\text { (kg/bln) }\end{array}$ & $\begin{array}{c}\text { Omset (dalam } \\
\text { ribuan/bln }\end{array}$ \\
\hline 1 & SUMATERA & 100 & 4.044 & 270.836 & 3.567 .898 \\
\hline 2 & JAWA & 26 & 2.600 & 43.483 & 206.324 \\
\hline 3 & BALI NUSA TENGGARA & 14 & 3.190 & 543.770 & 373.003 \\
\hline 4 & KALIMANT AN & 90 & 6.631 & 96.353 & 183.655 \\
\hline 5 & SULAWESI MALUKU & 62 & 2.360 & 28.510 & 69.226 \\
\hline 6 & PAPUA & 19 & 1.087 & 1.958 & 6.265 \\
\hline & TOTAL & $\mathbf{1 . 7 0 3}$ & $\mathbf{1 0 0 . 0 0 2}$ & $\mathbf{2 . 4 9 4 . 7 1 5}$ & $\mathbf{1 5 . 3 6 7 . 8 9 5}$ \\
\hline
\end{tabular}

(Kementerian Lingkungan Hidup, 2014)

Oleh karena pertumbuhan jumlah bank sampah yang cepat, segala upaya dilakukan untuk terus memperbaiki manajemen bank sampah. Kementerian Lingkungan Hidup mengeluarkan Peraturan Menteri Lingkungan Hidup No.13 tahun 2012 mengenai Pedoman Pelaksanaan Reduce, Reuse dan Recycle melalui Bank Sampah. Dalam peraturan tersebut, sistem pencatatan termasuk ke dalam salah satu dari mekanisme kerja bank sampah. Namun, pembahasan mengenai sistem pencatatan bank sampah sama sekali tidak pernah terpublikasi dan belum memiliki standar yang baku. Semakin kompleks aktivitas pada bank sampah dan kebutuhan transparansi keuangan pada semua pihak menjadi dua alasan kuat bahwa ini termasuk unsur yang penting bagi perkembangan bank sampah.

Fungsi pencatatan keuangan adalah untuk melaksanakan kegiatan secara efisien, membuat perencanaan yang efektif, sekaligus mengadakan pengawasan serta pengambilan keputusan yang tepat. Pelaksanaan aktivitas bank sampah membutuhkan dasar pencatatan dalam akuntansi yang tepat untuk menunjang 
pembuatan laporan keuangan. Aktivitas bank sampah banyak melibatkan nasabah yang mengharuskan adanya transparansi keuangan didalamnya. Ketika pencatatan keuangan telah sesuai maka akan menambah kepercayaan dari nasabah (masyarakat) terhadap bank sampah. Proses produksi pun semakin berkembang, pengelolaan sampah berjalan dengan baik, pemberdayaan masyarakat terpenuhi dan keuntungan pun akan bertambah.Berdasarkan latar belakang tersebut diatas, maka penulis tertarik untuk melakukan penelitian mengenai Rancangan Sistem Siklus Akuntansi Pada Bank Sampah.

\section{METODE PENELITIAN}

Jenis penelitian dalam penelitian ini adalah jenis penelitian kualitatif dengan metode deskriptif. Penelitian ini menghasilkan uraian sistem siklus akuntansi untuk bank sampah berdasarkan standar akuntansi dan aktivitas yang ada. Jenis penelitian ini menggunakan data primer dan sekunder yang disesuaikan dengan studi pustaka yang ada.

Data primer ialah berupa data yang menggambarkan aktivitas bank sampah berupa beberapa transaksi dari bank sampah Malang dan Malaka Sari juga buku manual penggunaan aplikasi bank sampah Malang. Sedangkan data sekunder ialah berupa data mengenai bank sampah berupa buku implementasi 3R melalui bank sampah Kementerian Lingkungan Hidup 2014. Selain itu juga Peraturan Menteri No.13 tahun 2012, SAK ETAP dan PSAK Syariah.

Objek penelitian ini terdiri dari responden dan paper atau data kepustakaan. Responden dalam penelitian ini adalah Pak Bambang Prakoso selaku pimpinan Bank Sampah Malaka Sari dan pihak Kementerian Lingkungan Hidup Deputi IV Bidang Pengelolaan Sampah terkhusus Pak Arif Sumardi selaku Kasubid Pembinaan Teknis dan Pak Esa selaku Kasubid Bank Sampah. Kemudian, data kepustakaan dalam penelitian ini adalah beberapa data transaksi bank sampah Malang, buku manual penggunaan aplikasi bank sampah Malang, beberapa contoh form bank sampah Malaka Sari, Peraturan Menteri No.13 tahun 2012, buku implementasi 3R melalui bank sampah dari Kementerian Lingkungan Hidup, SAK ETAP dan PSAK Syariah.

Teknik pengumpulan data yang dipakai pada penelitian ini adalah melalui wawancara, dokumentasi, kepustakaan, internet dan media cetak. Wawancara dilakukan secara langsung kepada Kepala Bidang Bank Sampah dan Kepala Bidang Pembinaan Teknis Kementerian Lingkungan Hidup perihal perkembangan bank sampah di Indonesia dan praktek bank sampah Malang sebagai percontohan dan pimpinan bank sampah Malaka Sari perihal aktivitas dan keuangan di bank sampah Malaka Sari. Arsip yang digunakan adalah arsip atau data-data yang berhubungan dengan sejarah berdirinya Bank Sampah, struktur organisasi, tujuan, jumlah Pengurus dan data sistem kerja dari mulai aktifitas penghimpunan, pengolahan, sampai penarikan. Hal ini dilakukan untuk mendapatkan landasan teori dan data yang dapat menunjang penelitian. Data kepustakaan lain yang digunakan ialah buku profil bank sampah Indonesia 
disusun oleh Kementerian Lingkungan Hidup, buku panduan sistem bank sampah dan 10 kisah sukses disusun oleh Yayasan Unilever, artikel berjudul pengelolaaan sampah kota Malang melalui bank sampah yang disusun oleh APEKSI dalam buku best practice kota-kota, dan beberapa skema pilah bank sampah.

Langkah analisis data yang dilakukan adalah sebagai berikut :

a. Menelaah seluruh data yang tersedia dari berbagai sumber, baik dari wawancara, pengamatan yang sudah dituliskan dalam catatan lapangan, dokumen pribadi, dokumen resmi, gambar, foto, dan sebagainya.

b. Reduksi data. Data yang telah dibaca, dipelajari dan ditelaah tersebut mungkin sangat banyak sekali jumlahnya, sehingga memerlukan reduksi (pengurangan, penyusutan atau penurunan) dengan cara membuat abstraksi-abstraksi. Ini merupakan usaha membuat rangkuman dengan tetap menjaga inti, proses dan pernyataan-pernyataan yang ada.

c. Menganalisis data untuk memahami proses siklus akuntansi.

d. Membuat sistem siklus akuntansi dengan menggunakan SAK ETAP dan PSAK Syariah sebagai pedoman.

e. Menyimpulkan hasil analisis dan pemberian saran.

\section{HASIL DAN PEMBAHASAN}

Siklus Akuntansi adalah sebuah proses atau alur pelaksanaan pencatatan akuntansi sampai pada laporan keuangan sehingga siap untuk pencatatan akuntansi periode berikutnya (Soemarso, 2004, hlm.90). Siklus akuntansi memiliki tiga tahapan yaitu tahap pencatatan, pengikhtisaran dan pelaporan. Tahap pencatatan adalah tahap mencatat semua bukti transaksi ke semua jurnal. Tahap pengikhtisaran adalah tahap dimana semua akun dikelompokkan dalam buku besar lalu dikumpulkan kembali pada neraca saldo dengan menampilkan saldo terkini yang telah disesuaikan. Tahap pelaporan adalah tahap pembuatan laporan keuangan. Dari penjelasan mengenai akun dan ketentuannya, semua itu akan diolah dalam siklus akuntansi yang digambarkan seperti berikut ini.

Langkah-langkah ini adalah prosedur akuntansi yang biasanya digunakan oleh perusahaan untuk mencatat transaksi dan membuat laporan keuangan (Kieso, Weygandt, \& Warfield, 2007). Penjelasan mengenai siklus akuntansi keuangan yang terdiri dari tahap pencatatan, pengikhtisaran dan pelaporan dapat dilihat dari bagan di bawah.

Dalam menyusun sistem siklus akuntansi Bank Sampah, dilakukan identifikasi terlebih dahulu mengenai jenis badan usaha dari bank sampah tersebut. Sebagian besar bank sampah diresmikan dalam bentuk badan usaha koperasi. Oleh karena itu, siklus akuntansi mengacu pada Standar Akuntansi Keuangan untuk Entitas Tanpa Akuntabilitas Publik (SAK ETAP). SAK ETAP dimaksudkan untuk digunakan entitas tanpa akuntabilitas publik.

Entitas tanpa akuntabilitas publik adalah Entitas yang tidak memiliki akuntabilitas publik signifikan dan entitas yang menerbitkan laporan keuangan 
untuk tujuan umum (general purpose financial statement) bagi pengguna eksternal. Contoh pengguna eksternal adalah pemilik yang tidak terlibat langsung dalam pengelolaan usaha, kreditur, dan lembaga pemeringkat kredit.

Selain SAK ETAP, sistem siklus akuntansi Bank Sampah juga mengacu pada Pernyataan Standar Akuntansi Keuangan Syariah (PSAK Syariah). Hal ini bertujuan untuk menghilangkan aktivitas yang tidak sesuai dengan syariah Islam. Beberapa aktivitas bank sampah dikaitkan dengan akad-akad syariah sebagai berikut.

a. Aktivitas jual beli sampah atau barang lainnya dan aktivitas peminjaman menggunakan akad murabahah. Menurut PSAK 102, murabahah adalah akad jual beli barang dengan harga jual sebesar biaya perolehan ditambah keuntungan yang disepakati dan penjual harus mengungkapkan biaya perolehan tersebut kepada pembeli.

b. Aktivitas koperasi menggunakan akad musyarakah. Menurut PSAK 106, musyarakah adalah akad kerjasama antara dua pihak atau lebih untuk suatu usaha tertentu, di mana masing-masing pihak memberikan kontribusi dana dengan ketentuan bahwa keuntungan dibagi berdasarkan kesepakatan sedangkan kerugian berdasarkan kontribusi dana. Dana tersebut meliputi aset kas atau aset nonkas yang diperkenankan oleh syariah.

\subsection{TAHAP PENCATATAN PADA BANK SAMPAH}

Dalam membangun sistem pencatatan, perlu diketahui bahwa ada beberapa yang harus disiapkan oleh bank sampah, yaitu :
a. Daftar akun
b. Daftar harga sampah
c. Daftar nasabah tabungan
d. Daftar nasabah pembiayaan

Setelah persiapan selesai dilakukan maka selanjutnya adalah aktivitasaktivitas pada bank sampah yang akan dicatat. Aktivitas-aktivitas pada bank sampah dibagi menjadi empat aktivitas yaitu :

\section{Aktivitas Penerimaan dan Penjualan Sampah}

Aktivitas penerimaan sampah terjadi ketika nasabah datang ke bank sampah membawa sampah yang sudah dipilah. Sampah ditimbang lalu nasabah diberikan form asli penimbangan sampah. Form salinan penimbangan sampah akan menjadi dasar pencatatan keuangan kemudian disimpan. Pencatatan dilakukan pada jurnal khusus pembelian sampah dan buku besar pembantu persediaan sampah. Aktivitas penjualan sampah terjadi ketika petugas bank sampah menjual sampah kepada konsumen atau pelapak. Aktivitas penjualan sampah menghasilkan bukti penjualan sampah yang menjadi dasar pencatatan dan disimpan. Pencatatan dilakukan pada jurnal khusus penjualan sampah dan buku besar pembantu persediaan sampah.

Penilaian tabungan nasabah dapat dimulai dari aktivitas penjualan sampah, sehingga pencatatan juga dilakukan pada jurnal khusus tabungan sampah, buku besar pembantu tabungan sampah dan buku tabungan sampah milik nasabah. Sampah yang telah terjual, sudah relevan untuk dicatat sebagai 
tambahan nominal dalam tabungan nasabah. Saran kepada pelaku bank sampah yaitu saat menjual sampah harus dipastikan sampah dijual secara keseluruhan. Hal ini dikarenakan sampah yang telah terjual dan yang belum akan menimbulkan masalah tabungan mana yang lebih dahulu diakui.

Bagan 1 Tahapan Aktivitas Penerimaan dan Penjualan Sampah



Sumber: Data diolah (2015)

Aktivitas lainnya pada bank sampah disediakan jurnal khusus dan jurnal umum. Setiap transaksi yang mengakibatkan kas bertambah atau berkurang akan dicatat dalam jurnal khusus tersebut, kecuali yang berkaitan dengan aktivitas yang dijelaskan sebelumnya. Terdapat pula jurnal umum untuk transaksi yang tidak bisa dicatat dalam jurnal khusus.

\section{Aktivitas Penerimaan Simpanan dan Pembagian SHU}

Simpanan dibagi menjadi tiga yaitu simpanan pokok, wajib dan sukarela. Simpanan pokok merupakan pembayaran nasabah sebagai syarat menjadi anggota koperasi. Simpanan pokok hanya dibayar satu kali di awal. Simpanan wajib merupakan pembayaran nasabah secara rutin sebagai kewajiban anggota koperasi. Sedangkan simpanan sukarela merupakan pembayaran nasabah secara sukarela dengan waktu yang tidak ditentukan.

Pencatatan pembayaran simpanan-simpanan ini dicatat pada jurnal khusus penerimaan kas dan buku besar pembantu simpanan anggota koperasi. Pembagian SHU merupakan bagi hasil kepada anggota koperasi yang dilaksanakan setiap periode koperasi. Pencatatan pembagian SHU ini dicatat pada jurnal khusus pengeluaran kas dan buku besar pembantu daftar SHU anggota koperasi.

Bagan 2. Tahapan Aktivitas Penerimaan Simpanan dan Pembagian SHU 


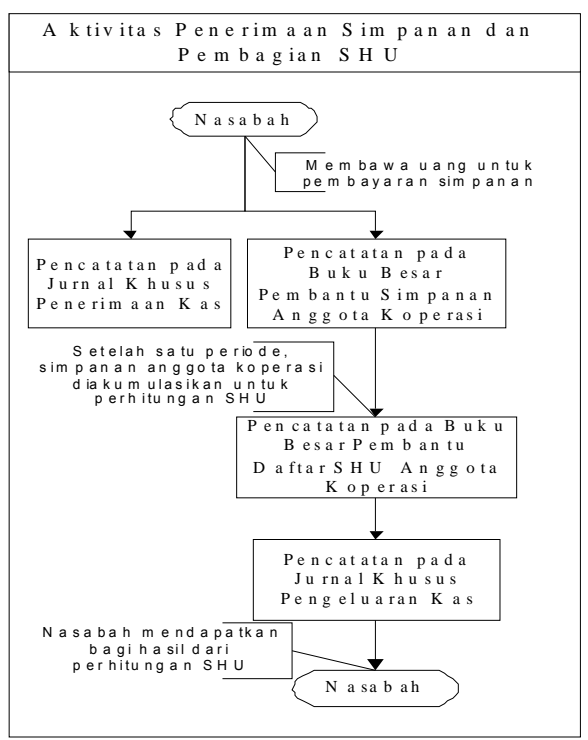

Sumber: Data diolah (2015)

\section{Aktivitas Jual Beli}

Bagan 3. Tahapan Aktivitas Jual Beli

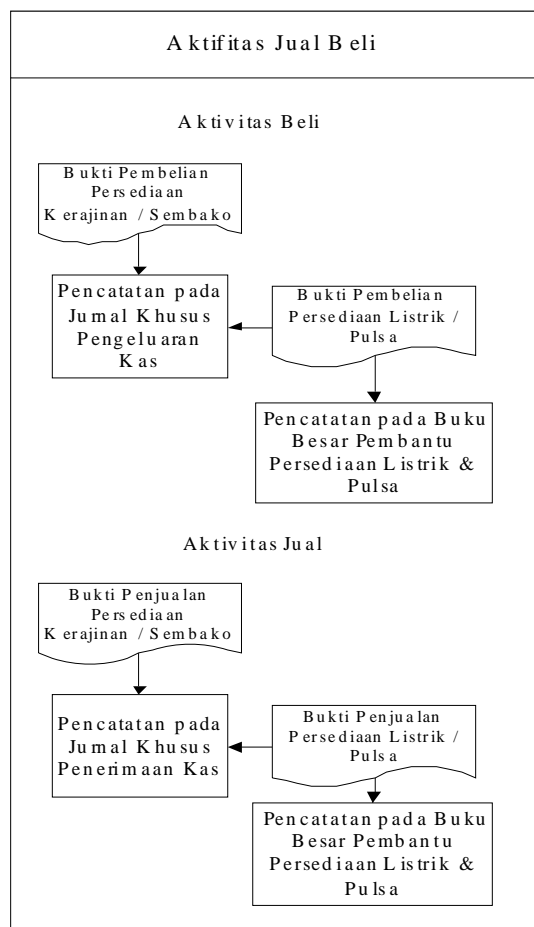

Sumber: Data diolah (2015) 
Beberapa aktivitas pada bank sampah, disesuaikan dengan usaha yang dijalankan bank sampah. Bank Sampah yang aktivitasnya jual beli listrik dan pulsa dapat menggunakan pencatatan ini. Pencatatan pembelian persediaan listrik/pulsa ini dicatat pada jurnal khusus pengeluaran kas. Sedangkan pencatatan penjualan listrik/pulsa dicatat pada jurnal khusus penerimaan kas. 4. Aktivitas Peminjaman

Bank Sampah yang aktivitasnya simpan pinjam dapat menggunakan pencatatan ini. Peminjaman dibagi dalam dua jenis yaitu peminjaman modal dan peminjaman baik (qardhul hasan). Peminjaman modal adalah peminjaman yang diperuntukkan pengembangan usaha atau pembelian barang, terdapat margin di dalamnya. Sedangkan peminjaman baik adalah peminjaman yang diperuntukkan kebutuhan hidup dengan syarat tertentu, tidak terdapat margin di dalamnya. Pencatatan pemberian peminjaman modal ini dicatat pada jurnal khusus pengeluaran kas. Pencatatan pemberian peminjaman baik ini dicatat pada jurnal khusus pengeluaran kas. Sedangkan pencatatan pelunasan peminjaman dicatat pada jurnal khusus penerimaan kas. Untuk kedua aktivitas tersebut (pemberian dan pelunasan) juga dicatat dalam buku besar pembantu nasabah pembiayaan.

\section{Bagan 4. Tahapan Aktivitas Peminjaman}

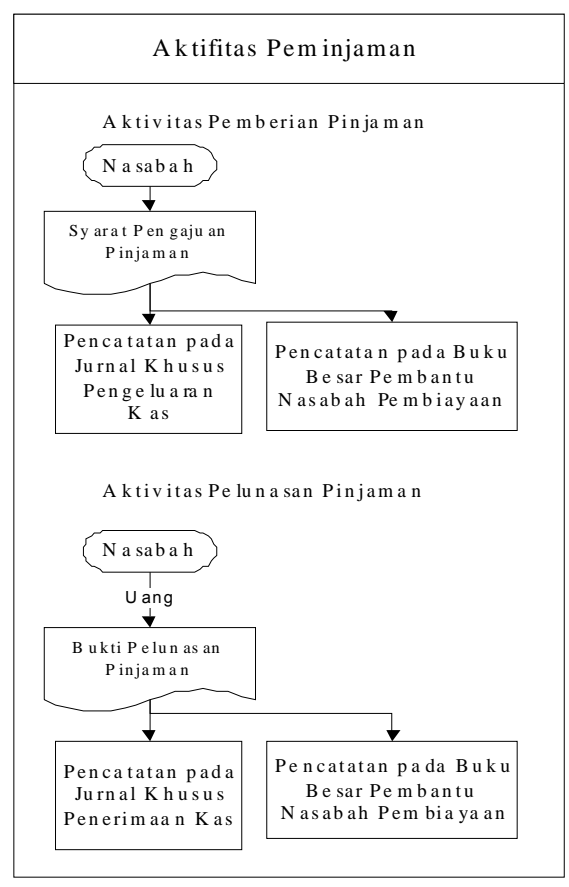

Sumber: Data diolah (2015)

5. Aktivitas Penerimaan dan Klaim Dana Sehat

Dalam bank sampah usaha sejenis asuransi terbagi dalam dua aktivitas, yaitu penerimaan dana sehat dan klaim. 
Bank sampah yang memiliki usaha sejenis ini dapat memakai pencatatan sebagai berikut.

Bagan 5. Tahapan Aktivitas Penerimaan dan Klaim Dana Sehat

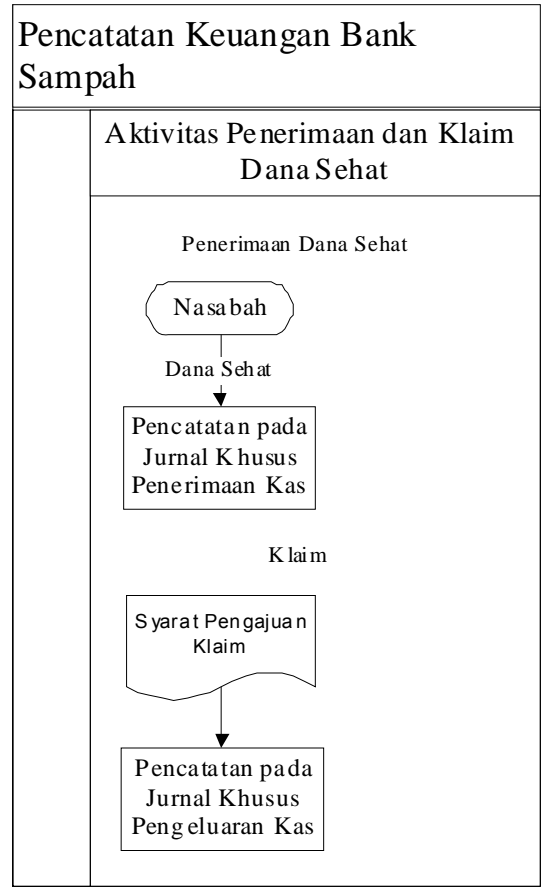

Sumber: Data diolah (2015)

Aktivitas pertama adalah penerimaan dana sehat. Dana sehat merupakan kumpulan dana dari peserta asuransi untuk memenuhi klaim. Pencatatan penerimaan dana sehat ini dicatat pada jurnal khusus penerimaan kas. Aktivitas kedua adalah klaim. Pencatatan klaim ini dicatat pada jurnal khusus pengeluaran kas.

Adapun beberapa form yang akan dipakai dalam tahap pencatatan ini adalah :

a. Buku besar pembantu persediaan sampah menyajikan informasi mengenai nilai saldo persediaan sampah yang dibeli dari nasabah.

b. Jurnal khusus tabungan sampah juga berfungsi untuk mencatat transaksi penarikan tabungan.

c. Buku besar pembantu tabungan nasabah adalah buku besar yang menginformasikan mengenai tabungan tiap nasabah bank sampah.

d. Jurnal khusus penerimaan kas adalah jurnal yang khusus mencatat transaksi yang berhubungan dengan terjadinya penambahan nilai kas.

e. Jurnal khusus pengeluaran kas adalah jurnal yang khusus mencatat transaksi yang berhubungan dengan terjadinya pengurangan nilai kas.

f. Jurnal umum yang merupakan jurnal untuk mencatat transaksi yang tidak 
bisa dicatat dalam jurnal khusus.

g. Buku besar pembantu simpanan anggota koperasi adalah buku besar yang menginformasikan mengenai simpanan para anggota koperasi baik simpanan pokok maupun simpanan wajib.

h. Buku besar pembantu daftar SHU (sisa hasil usaha) anggota koperasi adalah buku besar yang menginformasikan mengenai pembagian SHU para anggota koperasi.

i. Buku besar pembantu persediaan listrik \& pulsa merupakan buku besar yang menginfokan mengenai transaksi pembelian dan penjualan listrik dan pulsa.

j. Buku besar pembantu nasabah pembiayaan merupakan buku besar yang menginfokan mengenai pembiayaan para nasabah. Pada buku besar pembantu nasabah pembiayaan terdiri dari beberapa tabel sesuai dengan jumlah nasabah pembiayaan. Tiap tabel mewakili setiap keterangan pembiayaan yang dikenakan oleh nasabah.

Adapula jurnal yang akan dicatat dalam tahap pencatatan, terangkum dalam jurnal aktivitas pada Bank Sampah di bawah ini

Tabel 2. Jurnal Aktivitas Bank Sampah

\begin{tabular}{|l|l|}
\hline \multicolumn{2}{|c|}{ Aktivitas Umum } \\
\hline Pada saat Penghimpunan Sampah \\
\hline D & Persediaan sampah \\
\hline K & Titipan Sampah/Kas \\
\hline Pada saat Penjualan Sampah \\
\hline D & Kas \\
\hline K & Penjualan \\
\hline D & Harga Pokok Penjualan \\
\hline K & Pers ediaan Sampah \\
\hline Pada saat Pengakuan Tabungan \\
\hline D & Titipan Sampah \\
\hline K & Tabungan \\
\hline K & Pendapatan Administrasi \\
\hline Pada saat Penarikan Tabungan \\
\hline D & Tabungan \\
\hline K & Kas/Persd. Sembako \\
\hline Pada saat Tabungan ditukar sembako \\
\hline Dr & Tabungan \\
\hline Cr & Persediaan Sembako \\
\hline Pada saat Pemeliharaan Aktiva Tetap \\
\hline Dr & Beban Pemeliharaan Peralatan/Kendaraan/Gedung \\
\hline Cr & Kas \\
\hline
\end{tabular}




\begin{tabular}{|l|l|}
\hline \multicolumn{2}{|l|}{ Pembayaran Gaji } \\
\hline D & Beban Gaji Pengurus/ Pengrajin \\
\hline K & Kas / Utang Gaji \\
\hline Pembelian Asset \\
\hline D & Peralatan/Kendaraan \\
\hline K & Kas / Utang Usaha \\
\hline Pada saat Penerimaan Pelatihan \\
\hline D & Kas \\
\hline K & Pendapatan Pelatihan \\
\hline
\end{tabular}

\begin{tabular}{|l|l|}
\hline \multicolumn{2}{|c|}{ Pada Unit Usaha Koperasi } \\
\hline Pada saat Penerimaan Simpanan Pokok \\
\hline D & Kas \\
\hline K & Simpanan Pokok Koperasi \\
\hline Pada saat Penerimaan Simpanan Wajib \\
\hline D & Kas \\
\hline K & Simpanan Wajib Koperasi \\
\hline Pada saat Pembagian Bagi Hasil \\
\hline D & Hak bagi hasil anggota koperasi \\
\hline K & Kas \\
\hline Pada saat Penjualan Barang Kerajinan/ Sembako \\
\hline D & Kas \\
\hline K & Penjualan \\
\cline { 2 - 3 } D & Harga Pokok Penjualan \\
\hline K & Persediaan Kerajinan/ Sembako \\
\hline Pada saat Pembelian Kerajinan/ Sembako \\
\hline D & Persediaan Kerajinan/ Sembako \\
\hline K & Kas \\
\hline Pada saat Pembelian Persediaan Listrik dan Pulsa \\
\hline D & Persediaan listrik \& pulsa \\
\hline K & Kas \\
\hline Pada saat Pengakuan Keuntungan Jasa Listrik dan Pulsa \\
\hline D & Harga Pokok Penjualan \\
\hline K & Persediaan listrik \& pulsa \\
\hline D & Kas \\
\hline K & Penjualan \\
\hline
\end{tabular}




\begin{tabular}{|l|l|}
\hline \multicolumn{2}{|c|}{ Pada Unit Usaha Peminjaman } \\
\hline Pada saat Peminjaman Qardhul Hasan \\
\hline D & Piutang Qardhul Hasan \\
\hline K & Kas \\
\hline Pada saat Peminjaman Modal Produktif \\
\hline D & Piutang Usaha \\
\hline K & Kas \\
\hline K & Pendapatan Margin Ditangguhkan \\
\hline Pada saat Pembayaran Peminjaman \\
\hline D & \multicolumn{2}{|l|}{ Kas } \\
\hline K & Piutang Usaha/ Piutang Qardhul Hasan \\
\hline D & Pendapatan Margin Ditangguhkan \\
\hline K & Pendapatan Margin \\
\hline
\end{tabular}

\begin{tabular}{|l|l|}
\hline \multicolumn{2}{|c|}{ Pada Unit Usaha Dana Sehat } \\
\hline Pada saat penerimaan kontribusi \\
\hline D & Tabungan/ Kas \\
\hline K & Simpanan Dana Sehat \\
\hline \multicolumn{2}{|l|}{ Pada saat ada klaim asuransi } \\
\hline D & Simpanan Dana Sehat \\
\hline K & Kas \\
\hline
\end{tabular}

\begin{tabular}{|l|l|}
\hline \multicolumn{2}{|c|}{ Jurnal Penyesuaian } \\
\hline Penyusutan \\
\hline D & Beban Penyusutan Bangunan/Kenda raan/Peralatan \\
\hline K & Akumulasi Penyusutan Bangunan/Kendaraan/Peralatan \\
\hline Biaya Dibayar Dimuka \\
\hline D & Beban Sewa/Iklan \\
\hline K & Sewa/Iklan dibayar dimuka \\
\hline
\end{tabular}

\subsection{TAHAP PENGIKHTISARAN PADA BANK SAMPAH}

Setelah semua transaksi telah dicatat dalam jurnal, maka langkah selanjutnya adalah menggolongkan akun-akun sampai tersedianya neraca saldo. Penggolongan akun yang berasal dari jurnal khusus dan jurnal umum akan dicatat dalam buku besar. Setelahnya disusun neraca saldo kemudian jurnal penyesuaian. Dan dari jurnal penyesuaian akan disesuaikan kembali menjadi neraca saldo.

Buku besar merupakan tempat menggolongkan akun-akun yang terangkum dari jurnal. Pada buku besar terdiri dari beberapa tabel sesuai dengan jumlah akun yang ada pada bank sampah. Tiap tabel mewakili setiap akun yang akan diperhitungkan nilai debit dan kreditnya. Setelah buku besar semua akun 
dicatat, maka semua saldo akun akan dicatat pada neraca saldo. Neraca saldo merupakan tempat terangkumnya semua saldo akhir akun-akun dari buku besar. Dari seluruh transaksi yang tercatat dalam buku besar, perlu adanya penyesuaian beberapa akun yang menunjukkan keadaan sebenarnya di periode berjalan pada jurnal penyesuaian.

Jurnal penyesuaian merupakan jurnal untuk mencatat semua penyesuaian yang dibutuhkan beberapa akun.Setelah mencatat di jurnal penyesuaian, maka akun-akun tersebut dimasukkan ke buku besar agar saldo dari akun yang bersangkutan menunjukkan keadaan yang telah disesuaikan. Memasukkan penyesuaian ke dalam buku besar ketentuannya sama seperti yang dijelaskan sebelumnya, namun pada kolom jurnal ditulis “jurnal penyesuaian”.

\subsection{TAHAP PELAPORAN PADA BANK SAMPAH}

Laporan keuangan disediakan dalam rangka menyediakan informasi suatu entitas yang bermanfaat bagi sejumlah besar pengguna dalam pengambilan keputusan ekonomi. Laporan keuangan juga menunjukkan apa yang telah dilakukan manajemen atau pertanggungjawaban manajemen atas aktivitas yang telah dilakukan.

Laporan keuangan yang pertama di susun adalah laporan sisa hasil usaha. Dalam laporan sisa hasil usaha merupakan laporan yang menunjukkan laba atau rugi dari aktivitas keuangan yang terjadi dalam bank sampah. Pada laporan sisa hasil usaha terdiri dari akun-akun nominal yaitu akun pendapatan dan beban. Semua akun pendapatan yang ditampilkan dikurang dengan semua akun beban. Hasil dari selisih tersebut menunjukkan laba atau rugi bank sampah.Hasil laba atau rugi dari laporan sebelumnya akan dimasukkan ke dalam laporan perubahan ekuitas.

Dalam laporan perubahan ekuitas merupakan laporan yang menunjukkan perubahan akun ekuitas oleh beberapa aktivitas terkait. Pada laporan perubahan ekuitas terdiri dari akun modal, laba atau rugi dan penambah atau pengurang lainnya. Akun modal pada periode kemarin ditampilkan dengan penambah atau pengurang modal tersebut seperti laba atau rugi, pengambilan pribadi dan lainnya. Hasil dari laporan ini menunjukkan modal akhir periode berjalan.

Setelah laporan perubahan ekuitas, maka akan disusun neraca. Semua akun-akun riil kan kembali ditampilkan dalam laporan ini. Semua nominal akunakun riil tertulis seperti nominal hasil dari buku besar kecuali ekuitas. Nilai modal akan tertulis sesuai dengan laporan perubahan ekuitas. Neraca suatu entitas terdiri dari aset, kewajiban, dan ekuitas pada suatu waktu tertentu. Neraca merupakan laporan yang menunjukkan keseimbangan posisi antara aktiva yaitu asset dan pasiva yaitu kewajiban dan ekuitas. Pada neraca terdiri dari akunakun asset, kewajiban dan ekuitas. Semua akun tersebut disajikan dengan posisi kiri yaitu asset dan posisi kanan yaitu kewajiban dan ekuitas, kemudian keduanya sama-sama dijumlahkan. Hasil dari laporan ini menunjukkan kesamaan jumlah nominal antara sisi kiri dan kanan. Jika belum sama, maka terindikasi adanya kesalahan dalam pencatatan. 
Setelah neraca, maka akan disusun laporan arus kas. Dalam laporan arus kas akan dijelaskan mengenai penambahan dan pengurangan kas yang terjadi dalam periode berjalan. Laporan arus kas merupakan laporan yang menunjukkan keadaan kas selama periode berjalan. Pada laporan arus kas tertulis keterangan penambahan dan pengurangan kas yang terdiri dari aktivitas operasi, pendanaan dan investasi. Semua keterangan tersebut dihitung sehingga menghasilkan penambahan atau pengurangan kas selama periode tersebut. Penambahan atau pengurangan kas pada laporan ini akan disesuaikan dengan saldo awal kas sehingga menghasilkan saldo akhir kas. Hasil dari laporan ini menunjukkan bahwa saldo akhir kas harus sama dengan akun kas dalam perhitungan neraca saldo (setelah penyesuaian) sehingga dapat menjadi evaluasi akun kas.

Terakhir, laporan yang dibuat adalah catatan atas laporan keuangan. Akun-akun yang memiliki informasi yang belum terungkap pada laporan sebelumnya akan diungkapkan pada laporan ini. Catatan atas laporan keuangan merupakan laporan yang menunjukkan informasi akun-akun yang belum diungkapkan pada laporan-laporan sebelumnya. Pada catatan atas laporan keuangan terdiri dari tiga bagian yaitu bagian umum, bagian kebijakan akuntansi dan bagian penjelasan pos-pos neracadan perubahan dana. Bagian umum menjelaskan mengenai informasi umum dan pendirian bank sampah juga susunan pengurus. Bagian kebijakan akuntansi menjelaskan mengenai dasar penyajian laporan keuangan, aset tetap, pengakuan pendapatan, beban dan lainnya. Bagian penjelasan pos-pos neraca dan perubahan dana menjelaskan mengenai kererangan akun-akun yang belum diungkapkan dalam laporan keuangan sebelumnya dan perubahan dana periode ini dan periode sebelumnya. Keterangan akun-akun yang belum terungkap adalah unsur-unsur yang membangun nilai dalam suatu akun. Misalnya suatu akun persediaan sampah terdiri dari sampah plastik, sampah kertas dan lain-lain.

Seperti dijelaskan dalam siklus akuntansi, setelah pembuatan laporan keuangan terdapat jurnal penutup dan neraca saldo setelah penutup sebagai persiapan siklus akuntansi periode selanjutnya. Jurnal penutup merupakan sebuah jurnal yang menutup semua akun-akun nominal atau menjadikan saldo. Pada jurnal penutup terdiri dari akun-akun pendapatan, beban, ikhtisar laba rugi dan modal. Hasil dari jurnal penutup ini menunjukkan jurnal yang menutup akun-akun pendapatan dan akun-akun beban kemudian dialihkan selisihnya pada akun modal.

Setelah jurnal penutup, maka neraca saldo setelah penutupan akan disusun sebagai persiapan siklus akuntansi periode selanjutnya. Neraca saldo setelah penutupan merupakan neraca saldo yang disusun setelah jurnal penutup untuk mempersiapkan akuntansi periode selanjutnya. Pada neraca saldo setelah penutupan terdiri dari akun-akun riil dengan nominal saldo akhir masing-masing. Hasil dari neraca saldo setelah penutupan ini menunjukkan saldo akhir dari akun-akun yang akan menjadi saldo awal dalam siklus akuntansi berikutnya.

Dalam menyajikan laporan keuangan tidak sama seperti tahapan penyusunan di atas. Jika penyusunan laporan keuangan di atas diawali dengan 
laporan sisa hasil usaha, namun lain hal dengan penyajian laporan keuangan. Penyajian laporan keuangan secara berurutan adalah neraca, laporan sisa hasil usaha, laporan perubahan ekuitas, laporan arus kas dan terakhir catatan atas laporan keuangan.

\section{SIMPULAN}

Berdasarkan pembahasan yang telah dijelaskan pada bab-bab sebelumnya, maka dapat disimpulkan mengenai jawaban masalah yang diteliti sebagai tujuan penelitian yang terkait dengan penelitian ini.

a. Pada siklus akuntansi bank sampah di Indonesia memiliki perbedaan masingmasing dan belum memiliki suatu pedoman baku. Ada yang sistem pencatatannya hasil rancangan sendiri dan ada pula yang berasal dari perusahaan atau yayasan yang memberikan bantuan CSR kepada bank sampah tersebut. Perbedaan itu juga terdapat pada teknis pencatatan ada yang manual dan ada pula yang menggunakan sistem komputer. Dari keduanya tidak memiliki suatu pedoman pencatatan. Namun, seperti dijelaskan sebelumnya, bahwa masih terdapat kekurangan dalam sistem pencatatannya yakni masih ada sumber daya bank sampah yang belum terungkap.

Dalam penjelasan tahap pencatatan dan pengikhtisaran bank sampah disajikan berdasarkan standar akuntansi yang berlaku dan disesuaikan dengan aktivitas yang ada di bank sampah. Pencatatan keuangan ini disusun dengan pedoman siklus akuntansi yang menyajikan beberapa form pencatatan yang memudahkan dalam mencatat transaksi dan saling berkaitan. Form tersebut terdiri dari buku besar pembantu, jurnal khusus, jurnal umum, buku besar, jurnal penyesuaian dan neraca saldo. Laporan keuangan disusun dengan pedoman siklus akuntansi yang menyajikan secara berurutan neraca, laporan sisa hasil usaha, laporan perubahan ekuitas, laporan arus kas dan catatan atas laporan keuangan. Dengan penyajian laporan keuangan ini semua sumber daya dapat diungkapkan dan dilaporkan dengan baik.

b. Bank sampah di Indonesia telah mengalami perkembangan yang signifikan dalam segi jumlah bank sampah, nasabah juga omset. Kementerian Lingkungan Hidup menjadi instansi yang fokus dalam pengembangan bank sampah yaitu Deputi IV bagian Pengelolaan Sampah diharapkan melakukan inovasi-inovasi dalam kebijakan yang dikeluarkan. Salah satunya adalah kebijakan mengenai sistem pencatatan keuangan pada bank sampah. Perlu adanya kesetaraan dalam sistem pencatatan untuk seluruh bank sampah di Indonesia. Dengan begitu bank sampah di Indonesia akan mempunyai kualitas pencatatan keuangan yang sama dan juga akan lebih mudah untuk dievaluasi.

c. Demi mencapai pencatatan keuangan bank sampah yang lebih profesional, maka sistem pencatatan keuangan dan laporan keuangan bank sampah 
pada skripsi ini dapat diterjemahkan dalam sebuah aplikasi komputer keuangan bank sampah. Aplikasi ini dapat diakses oleh seluruh bank sampah di Indonesia dan terintegrasi ke Kementerian Lingkungan Hidup. Dengan demikian, pemantauan akan semakin baik dan terjalinnya komunikasi antar bank sampah di Indonesia.

\section{DAFTAR PUSTAKA}

APEKSI. (2014). Best Practice Kota-Kota Jilid 9 : Pengelolaan Sampah Kota Malang Melalui Bank Sampah. Jakarta.

Asisten Deputi Pengelolaan Sampah. (2013). Profil Bank Sampah Indonesia 2012. Jakarta : Kementerian Lingkungan Hidup Republik Indonesia.

Assisten Deputi Pengelolaan Sampah, Kementerian Lingkungan Hidup. (2014). Implementasi 3R Melalui Bank Sampah. Jakarta: Kementerian Lingkungan Hidup Republik Indonesia 2014.

Ikatan Akuntan Indonesia (IAI). (2007). Standar Akuntansi Keuangan Nomor 106: Akuntansi Musyarakah. Jakarta: Dewan Standar Akuntansi Keuangan Syariah IAI.

Ikatan Akuntan Indonesia (IAI). (2009). Standar Akuntansi Keuangan Entitas Tanpa Akuntabilitas Publik (SAK ETAP). Jakarta: Dewan Standar Akuntansi Keuangan IAI.

Ikatan Akuntan Indonesia (IAI). (2013). Standar Akuntansi Keuangan Nomor 103: Akuntansi Murabahah. Jakarta: Dewan Standar Akuntansi Keuangan Syariah IAI.

Kementerian Lingkungan Hidup. (2012). Peraturan Menteri Negara Lingkungan Hidup Republik Indonesia Nomor 13 Tahun 2012 tentang Pedoman Pelaksanaan Reduce, Reuse dan Recycle Melalui Bank Sampah. Jakarta: Kementerian Lingkungan Hidup Republik Indonesia.

Kementerian Lingkungan Hidup. (2014). From trash to cash. 14 April 2012. http://www.menlh.go.id

Kieso, Donald E.; Weygandt, Jerry J.; Warfield, Terry D. (2007). Akuntansi Intermediate ed. 12. Jakarta: Erlangga

Reeve, James M., et. al. (2009). Pengantar Akuntansi: - Adaptasi Indonesia. Jakarta: Salemba Empat.

Soemarso. (2004). Akuntansi Suatu Pengantar. (4 ${ }^{\text {th }}$ ed.). Jakarta: Salemba Empat. 
Yayasan Unilever Indonesia. (2013). Panduan Sistem Bank Sampah \& 10 Kisah Sukses. Jakarta: Yayasan Unilever Indonesia. 